\title{
Evaluation of Global Soil Wetness Project Soil Moisture Simulations
}

\author{
By Jared K. Entin \\ Department of Meteorology, University of Maryland, College Park, Maryland, U.S.A.
}

\begin{abstract}
Alan Robock
Department of Environmental Sciences, Rutgers - The State University of New Jersey, New Brunswick, New Jersey U.S.A.
\end{abstract}

\section{Konstantin Y. Vinnikov}

Department of Meteorology, University of Maryland, College Park, Maryland, U.S.A.

\section{Vladimir Zabelin}

Russian Hydrometeorological Center, Moscow, Russia

\section{Suxia Liu}

Department of Hydrology, Institute of Geography, Chinese Academy of Sciences, Beijing, China

\author{
A. Namkhai \\ Environmental Consulting and Assessment Company, Ulaanbaatar, Mongolia \\ and
}

Ts. Adyasuren

Ministry of Nature and the Environment, Ulaanbaatar, Mongolia

(Manuscript received 1 March 1998, in revised form 10 November 1998)

\begin{abstract}
To produce a global soil moisture "data set," ten different land surface models were forced with meteorological observations for a two-year period (1987-88) for the Global Soil Wetness Project (GSWP). We compare observed plant-available soil moisture in the top 1-m soil layer to the same quantity generated by the models. Our soil moisture observations are from grasslands and agricultural regions in Russia, Illinois (USA), China, and Mongolia.

None of the models does a good job of producing the actual soil moisture value for any of the regions. Thus, GSWP has not yet demonstrated the ability to produce global soil wetness data sets. Once the bias is removed, the models do a fairly good job of reproducing the seasonal cycle of soil moisture for the various areas. The model biases are different in different locations, so correcting them with a simple adjustment of the mean will not produce correct results. Better specification of parameters, or better representation of physical and biological processes, is still needed to improve these models.

Future GSWP experiments should be conducted for a longer time period. They should emphasize catchment scale validation and higher time resolution of model output. Increased soil moisture observations, possibly incorporating satellite measurements, also would greatly improve a second project.
\end{abstract}

Corresponding author: Alan Robock, Department of En-

vironmental Sciences, Rutgers - The State University of

New Jersey, 14 College Farm Road, New Brunswick, NJ

08901-8551, USA. E-mail: robock@envsci.rutgers.edu

(C) 1999 , Meteorological Society of Japan 


\section{Introduction}

The interaction between the land surface and the lowest layer of the atmosphere plays a critical role in determining both day-to-day weather and long term climate regimes (Namias, 1991; Delworth and Manabe, 1988). In an effort to better understand the complex interactions that occur at the surface, scientists have developed numerous land surface models (LSMs), beginning with the simple bucket model (Budyko, 1956; Manabe, 1969), and evolving to more complicated models - such as the Simple Biosphere model (SiB; Sellers et al., 1986) and the Biosphere Atmosphere Transfer Scheme (BATS; Dickinson et al., 1986) - that explicitly parameterize the effects of vegetation. Despite its limitations, the bucket model was incorporated into many general circulation models (GCMs) because of its simple design and minimal requirements in terms of input parameters and computation time. For a long time, the more complex models were not rigorously tested because of a lack of necessary input parameters and the observational data required to validate the results. Nevertheless, they are now being incorporated into GCMs. Recently, the SiB model has been simplified, reducing the number of input parameters it requires. The result is the Simplified $\mathrm{SiB}$ (SSiB) model (Xue et al., 1991). At the same time, additional LSMs, such as Mosaic (Koster and Suarez, 1992) and the Interaction between Soil, Biosphere, and Atmosphere (ISBA) model (Noilhan and Planton, 1989), have been developed with various new features and different emphases. More complex models require more input parameters at each grid box. In the 1994 Atmospheric Model Intercomparison Project (AMIP) (Gates, 1992) comparing 30 different GCMs, only four of the models contained parameterizations more complex than the bucket model, and five used prescribed soil moisture (Robock et al., 1998). Since then many GCMs have been upgraded with various newly developed LSMs. Whether the additional physical realism compensates for the errors introduced by the uncertainty in the required parameters is an unsolved question.

There are various approaches to validation of LSMs, as discussed in the plan of the Project for Intercomparison of Land-surface Parameterization Schemes (PILPS - Henderson-Sellers et al., 1993). One can force an LSM with artificial, modelgenerated atmospheric conditions and compare to the GCM simulation (Phase 1), force the LSM with actual observations and validate with observed water balance components (Phase 2), or conduct online, interactive tests with the LSM embedded in and interacting with a GCM (Phases 3 and 4). GSWP uses the same philosophy as PILPS Phase 2, forcing the LSMs with actual observations. A disadvantage of these off-line tests is that the LSM will not be able to come to equilibrium with, and interact with, the model atmosphere. Theoretically, this interaction may compensate for some LSM biases, although we know of no such demonstration. A related test was the AMIP experiment in which soil moisture simulations by 30 different GCMs were evaluated (Robock et al., 1998). While the models did not function very well, it was difficult to separate the effects of erroneous precipitation forcing (as simulated by the models), from problems with the LSMs. Off-line experiments gain an advantage as a testing tool because it is easier to compare models when all the models are forced with the same, more realistic, forcing. Thus, off-line experiments have been the primary form of validation, in addition to the fact that off-line experiments are generally easier and quicker to perform. Off-line experiments using our Russian data have served as valuable tools for evaluating and improving LSMs (e.g., Robock et al., 1995a; Schlosser et al., 1997a; Yang et al., 1997).

In the past, some GCMs specified soil moisture with a pre-generated soil moisture "data set." They were created by forcing an LSM, such as the bucket or $\mathrm{SiB}$, with observed meteorology data; Mintz and Serafini (1981, 1989, 1992), Schemm et al. (1992), and Liston et al. (1993) are three such "data sets." Although recently GCMs have become more complete and most now have incorporated an LSM, many still use these "data sets" for initialization or for subsurface climatology. In addition, in some forecast models these "data" are used for subsurface climatology, and the model fields are relaxed toward these values with a specified time scale. Actually, these "data sets" are just outputs of LSMs forced with climatological observations (Mintz and Serafini, 1981, 1989, 1992) or time-dependent observations (Schemm et al. 1992; Liston et al., 1993). Unfortunately, in areas with existing soil moisture observations, the "data sets" do not match well with the observations (Robock et al., 1995b, 1998; Matsuyama and Masuda, 1997). It is partly for this reason that the Global Soil Wetness Project (GSWP) was created.

If a soil moisture "data set" is to be used to initialize an LSM, then the "data set" must be calculated with the same LSM, even if the LSM is known to produce a bias in soil moisture. Otherwise, there will be spinup problems with the model trying to adjust from the initial values to its own climatology. A more satisfying solution is to use an LSM that accurately reproduces observations, and then use actual observations as initial conditions. This may involve some combination of in situ observations, remote sensing, and land data assimilation schemes.

The goal of GSWP is to develop a new more reliable global soil moisture data set. The basic philosophy is that if an LSM is good enough, and if the input data are sufficiently accurate, then the LSM can 
produce accurate fields of all the important terms in the land hydrological balance - soil moisture, evaporation, and runoff. If the model outputs do not agree with observations, then GSWP provides an opportunity to evaluate the causes of the disagreement. Oki et al. (1997) have suggested that in some regions there are not enough rain gauges to produce sufficiently accurate precipitation forcing. However, since all the LSMs have the same forcing, if they produce different soil moisture, then model differences will be the cause. This is one of the critical reasons for taking the off-line approach to land-surface modeling in GSWP, as opposed to one of the other methods.

The International Satellite Land Surface Climatology Project (ISLSCP) developed a CD-ROM set (Sellers et al., 1995; Meeson et al., 1995) containing meteorological observations to be used to force LSMs. The ISLSCP data set contains parameters required by the more complex models over the whole globe as well as forcing data for two years, 19871988. This rich set of input data allows us to evaluate model performance globally.

Improving our understanding of the land surface system is critical in understanding and interpreting climate change. How plants will react to an incipient change in temperature and precipitation will determine not only the plants' future, but their reaction will also play an interactive role with climate change and could develop into an important feedback. Better understanding of the land-surface system will lead to more complete knowledge of where, and under what circumstances, vegetation will have an accelerating, mitigating, or negligible impact on climates that are undergoing change.

This paper describes the progress we have made in validating the soil moisture produced by LSMs and points out areas where we believe more testing needs to be done. Section 2 of the paper explains why comparison with soil moisture observations is important for validating LSMs. Section 3 describes the data sets of soil moisture observations and Section 4 briefly discusses the different LSMs used in the GSWP experiment. Section 5 presents results of the comparisons we made, using time series of area averages of soil moisture. Conclusions are presented in Section 6, and suggestions for future research are offered in Section 7.

\section{Why use soil moisture for model valida- tion?}

Robock et al. (1998) provide a detailed rationale for why it is critical to pay careful attention to soil moisture when considering the performance of GCMs. Here we summarize these reasons. Soil moisture affects latent heat flux, and hence the partitioning of outgoing convective fluxes between sensible and latent heat, with a strong effect on the re- sulting surface temperature. Soil moisture, in some models, also affects surface albedo: wetter surfaces are darker, which also affects surface temperature.

Although Koster and Milly (1997) show that it is the relationship between the dependence of evapotranspiration and runoff on soil moisture that is important, not the absolute amount of soil moisture (with a simple monthly water balance simulation of complex land surface models, which ignores cryospheric processes), soil moisture itself is important for vegetation and agriculture. One of the most dire predictions of global warming is mid-latitude summer drought in the important agricultural regions of the Northern Hemisphere (Manabe et al., 1981; Houghton et al., 1996; Watson et al., 1996). Drought of this type would be due to a soil moisture deficiency. Plants grow or wilt due to the amount of soil moisture, not the fluxes. Therefore, evaluation of the ability of models to correctly simulate soil moisture is crucial to understand how well these models can calculate the impacts of global warming. Also, flood events can be linked to soil moisture excess (Giorgi et al., 1996). In order to properly simulate both of these aspects when considering climate change, the soil moisture calculation must be correct.

Any parameterization of physical quantities should be correct for the right physical reasons. Soil moisture, along with snow cover, is also the most important component of meteorological memory for the climate system over land. Delworth and Manabe (1993) have shown that varying soil moisture (as opposed to fixed soil moisture) induces a redder spectrum (greater persistence) in the simulated climate by retaining the hydrological signature of anomalies for time scales longer than those of the atmosphere alone. Soil moisture anomalies should also be important for more accurate seasonal forecasts.

\section{Soil moisture data sets}

Four soil moisture data sets were used in the evaluation discussed in this,paper. Taken together, they encompass a range of soil types and climatic regions. The data primarily originate from grasslands or agricultural areas. All data are available from the Global Soil Moisture Data Bank (http://www.envsci.rutgers.edu/ robock). The location of the stations and regions used are shown in Fig. 1. In all the evaluations in this paper we used plant-available soil moisture in the top $1 \mathrm{~m}$ of soil. The plant-available soil moisture is the total soil moisture minus the wilting level of the same layer of soil.

\subsection{Russia}

This data set is the output of a system for monitoring soil moisture at agricultural fields in the former Soviet Union (hereafter referred to as Russia). 


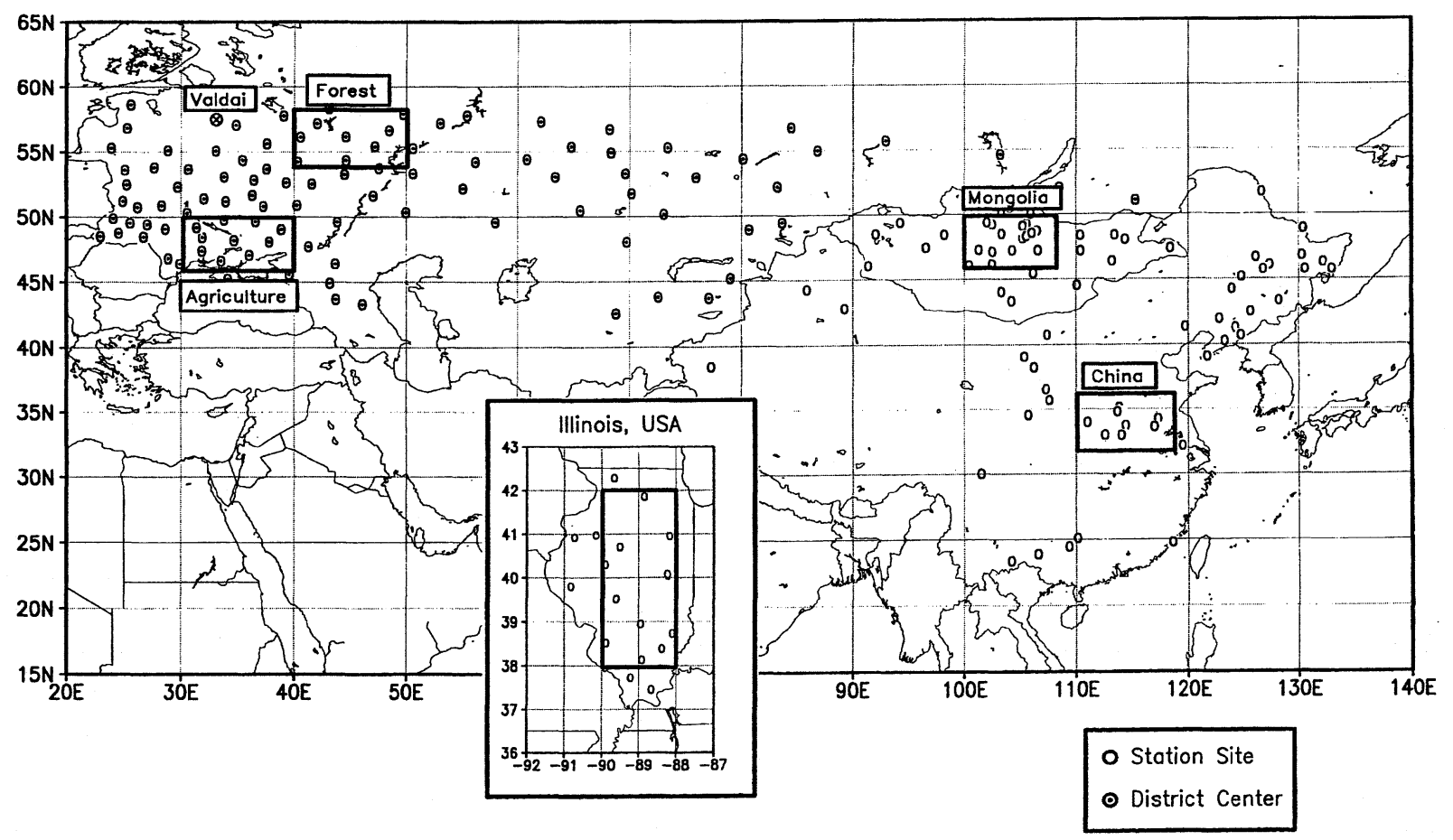

Fig. 1. Location of the soil moisture observation stations. District centers, whose observations consist of an average of surrounding soil moisture stations, are also indicated. Boxes used for spatial averages in Figs. 2-3 are indicated.

The data set contains plant available soil moisture, observed using a gravimetric technique, for the upper $20-\mathrm{cm}$ and $1-\mathrm{m}$ soil layers at agricultural fields with winter wheat crops and spring wheat crops (given separately) for 102 administrative districts of the former Soviet Union, in the grain belt of Russia. A limitation of this data set is that data were only taken during the growing period, from early April through late October. The data were observed roughly every ten days, on the $8 \mathrm{th}, 18 \mathrm{th}$, and either the 28 th or the last day of each month. On average each district contains an area of $30,000 \mathrm{~km}^{2}$, with a range of $10,000-100,000 \mathrm{~km}^{2}$. For the analyses reported in this paper, the measurements of six stations (on average) were used for each district with equal weights.

An advantage of this data set is that we have observations from 2 independent vegetation types for the same region. The agreement between them (Figs. 2-3) supports their validity for evaluation of LSMs. The small differences are the result of the different seasonal cycles of phenology of the two crops (Vinnikov et al., 1996b).

This data set was assembled specifically to be used to evaluate the GSWP (Vinnikov et al., 1997). The data start, however, in 1957, and this 40year data set will soon be described and released. Vinnikov and Yeserkepova (1991) describe a data set of 50 Russian soil moisture stations (now expanded to 130), where measurements were made at grass-covered fields, but the data set ends in 1985 , so cannot be used for GSWP. The data from Valdai, Russia $\left(57.6^{\circ} \mathrm{N}, 33.1^{\circ} \mathrm{E}\right.$; Fig. 1) extend from 1960 through 1990 (Vinnikov et al., 1996a; Schlosser et al., 1997b), and are being used to evaluate most of these same models as part of PILPS Phase 2(d).

\subsection{Illinois}

The Illinois data set is soil moisture observations from 18 different stations in the state of Illinois, USA, (Hollinger and Isard, 1994). At all stations the soil moisture was observed from a grass plot. Measurements were taken by neutron probe and calibrated by gravimetric observations. Soil moisture was measured for the top $10 \mathrm{~cm}$ and then for each 20 $\mathrm{cm}$ layer below, down to a depth of two meters. The data were observed roughly three times a month but not on any specific schedule, nor on the same day for all of the stations.

\subsection{China}

The Chinese data set consists of 43 stations, described in detail by Entin et al. (1999). The soil moisture observations were taken using a gravimetric technique for each $10-\mathrm{cm}$ layer down to a depth of $1 \mathrm{~m}$, with the first layer divided into two $5-\mathrm{cm}$ layers. The data were observed on the same time schedule as the Russian data, although for the full year. There is a variety of vegetation present in the network, but all fall into either an agricultural or grassland category.

The data were originally recorded as a percent wetness by mass of dry soil. Using soil density in- 

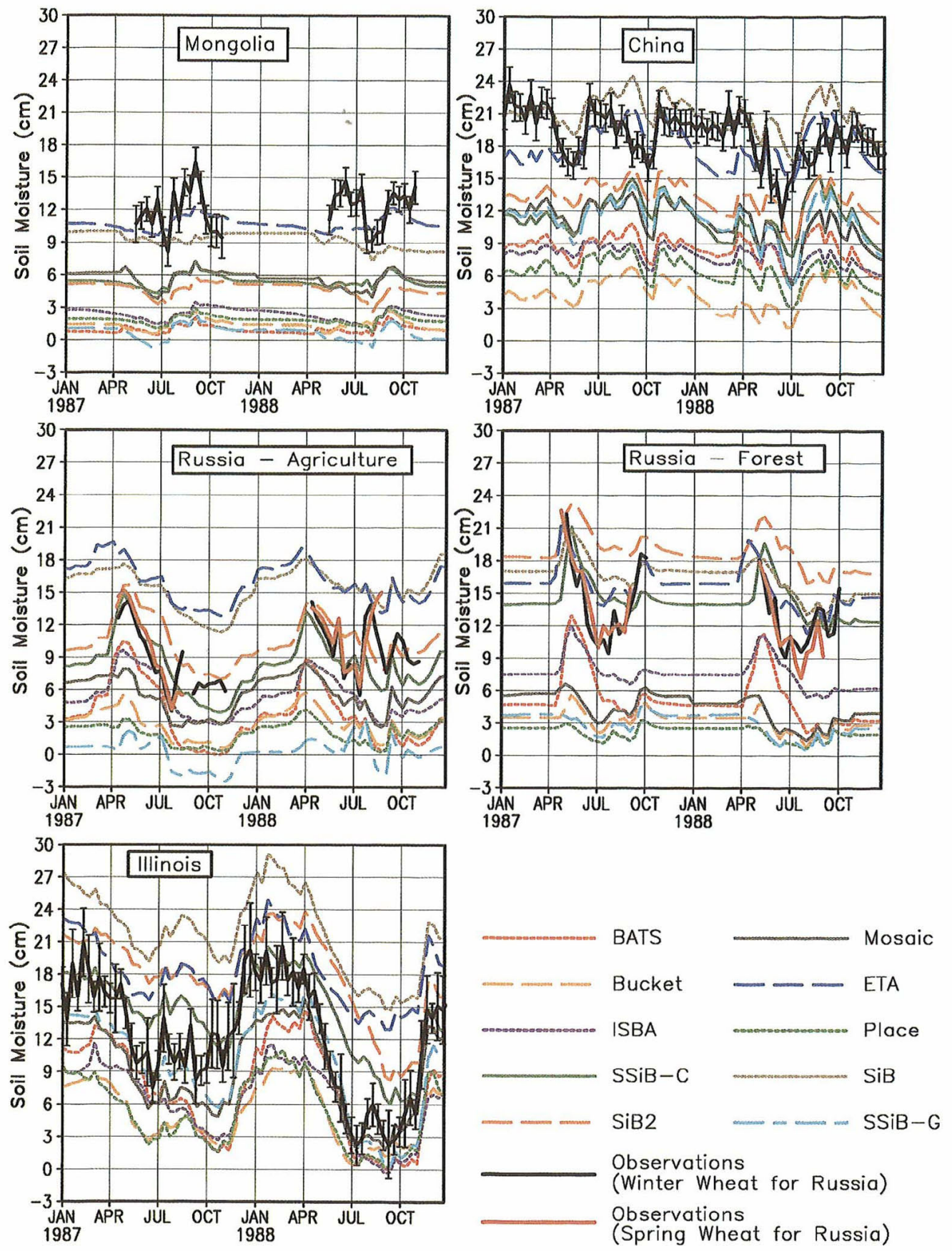

Fig. 2. Two-year time series of plant-available soil moisture in the top $1 \mathrm{~m}$ as generated by tne ten models, for the specified areas (Fig. 1). The boxes are at $30-40^{\circ} \mathrm{E}, 46-50^{\circ} \mathrm{N}$ for Russia Agriculture; $40-50^{\circ} \mathrm{E}, 54-58^{\circ} \mathrm{N}$ for Russia Forest; $90-88^{\circ} \mathrm{W}, 38-42^{\circ} \mathrm{N}$ for Illinois; $110-118^{\circ} \mathrm{E}, 32-36^{\circ} \mathrm{N}$ for China; and $100-108^{\circ} \mathrm{E}, 46-50^{\circ} \mathrm{N}$ for Mongolia. Corresponding soil moisture observations for the top $1 \mathrm{~m}$ are also displayed, along with the 1-standard-deviation confidence interval from the Kagan (1979) procedure.

formation available for each layer in each individual site, we determined the volumetric soil moisture. In addition, the wilting level of each layer was measured in terms of percent wetness by mass of dry soil and then converted, again by using the soil density, into a volumetric measure. This value was subtracted from the soil moisture observation to obtain the plant-available soil moisture for each layer, and for the top meter as a whole.

\subsection{Mongolia}

The Mongolian data set consists of 40 stations. Twenty-three sites have pasture vegetation, 15 have wheat, and two have both. All the observations were 

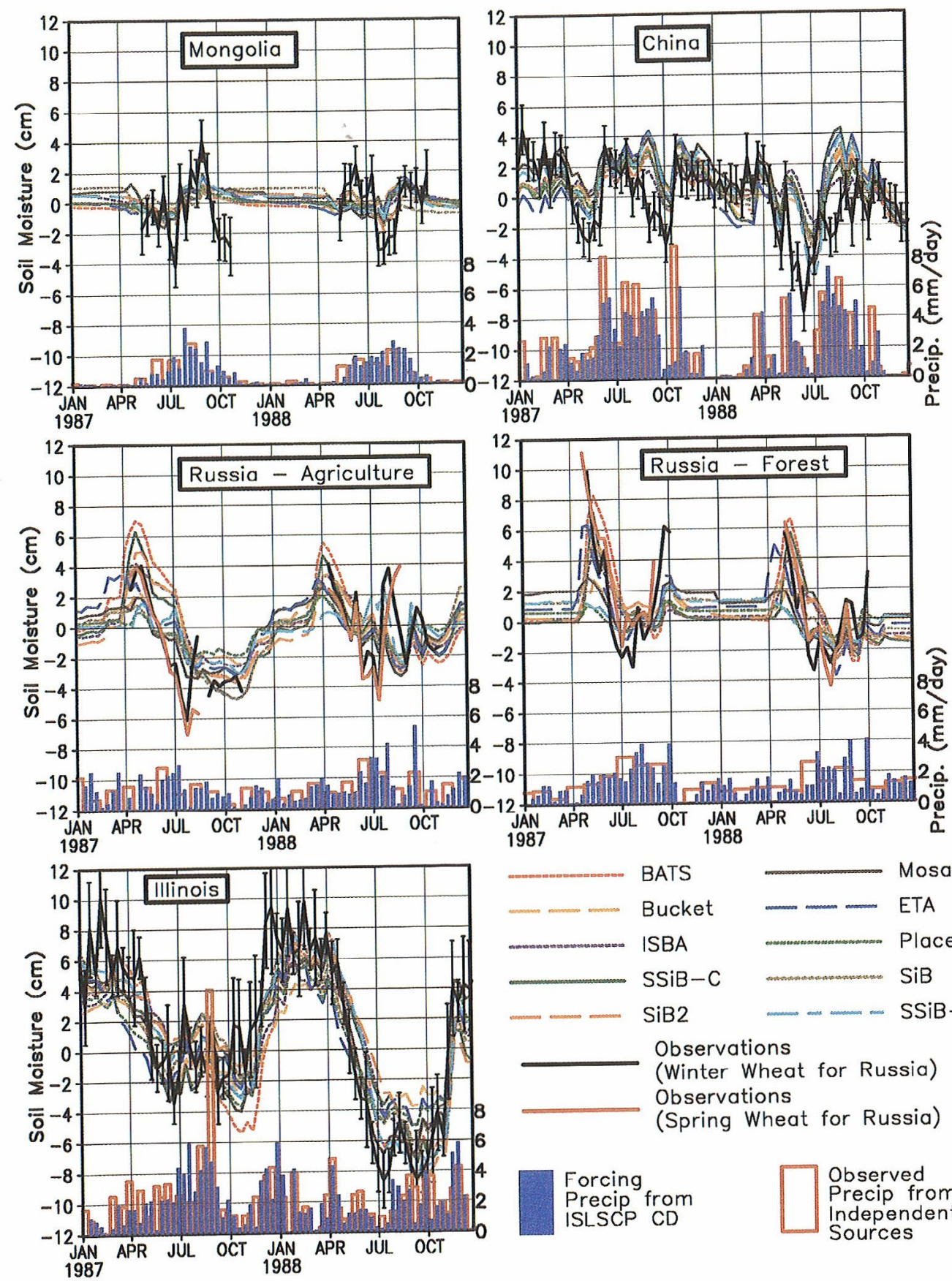
1987

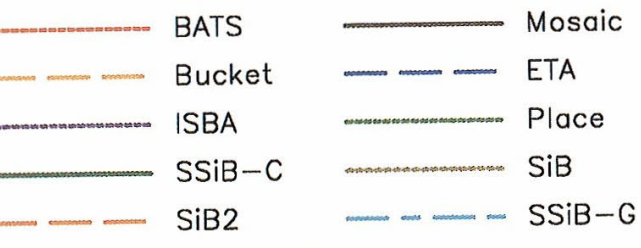

Observations

(Winter Wheat for Russia) Observations (Spring Wheat for Russia)
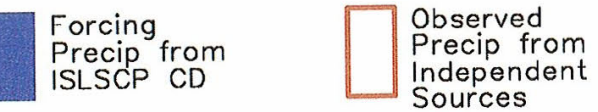

Fig. 3. Same as Fig. 2, but the average value for 1988 for each model has been subtracted from the model outputs. The observations have also been adjusted by subtracting out their 1988 mean. Precipitation for the designated areas is also given at the bottom of each graph. The forcing data come from the ISLSCP CD. Observed precipitation for China is an average of at least five observing stations located inside the China Box. Observed precipitation for Illinois is an average of at least two observing stations located inside the Illinois Box. Precipitation data for Russia and Mongolia are from Dai et al. (1997).

taken using the gravimetric technique for each 10$\mathrm{cm}$ layer of soil, down to $1 \mathrm{~m}$. Soil moisture was observed three times a month, on the 7 th, 17 th, and 27 th of the month, from April through the end of October, and is described in detail by Robock et al. (1999).

\section{Soil moisture schemes}

Ten diffcrent groups have contributed model runs to the GSWP experiment (Table 1). Changes were made from the published versions of some of the models for this particular experiment. For example, 
Table 1. Land surface models that participated in GSWP.

\begin{tabular}{|c|c|c|c|}
\hline Model & Group & Location & Reference \\
\hline BATS & Univ. of Arizona & United States & Dickinson et al. (1986) \\
\hline Bucket & $\begin{array}{l}\text { Center for Climate System } \\
\text { Research, Univ. Tokyo \& } \\
\text { National Institute for } \\
\text { Environmental Studies }\end{array}$ & Japan & $\begin{array}{l}\text { Budyko (1956); } \\
\text { Manabe (1969) }\end{array}$ \\
\hline ETA & $\begin{array}{l}\text { National Centers for } \\
\text { Environmental Prediction }\end{array}$ & United States & Chen et al. (1996) \\
\hline ISBA & Météo-France & France & Noilhan and Planton (1989) \\
\hline Mosaic & $\begin{array}{l}\text { Goddard Space Flight Center- } \\
\text { Hydrology Group }\end{array}$ & United States & Koster and Suarez (1992) \\
\hline Place & $\begin{array}{l}\text { Goddard Space Flight Center- } \\
\text { Mesoscale Group }\end{array}$ & United States & Wetzel et al. (1995) \\
\hline $\mathrm{SiB}$ & Japan Meteorol. Agency & Japan & Sellers et al. (1986) \\
\hline $\mathrm{SiB} 2$ & Colorado State Univ. & United States & Sellers et al., $(1996 \mathrm{a}, \mathrm{b})$ \\
\hline SSiB-G & $\begin{array}{l}\text { Goddard Space Flight Center } \\
\text { Climate Group }\end{array}$ & United States & Xue et al. (1991) \\
\hline $\mathrm{SSiB}-\mathrm{C}$ & $\begin{array}{l}\text { Center for Ocean-Land- } \\
\text { Atmosphere Studies }\end{array}$ & United States & Xue et al. (1991) \\
\hline
\end{tabular}

the Bucket model was altered to assume a $200-\mathrm{cm}$ root-zone, as opposed to the usual $100-\mathrm{cm}$. Effectively this doubles the field capacity, allowing the model to hold more water when the seasons shift from wet to dry. Evaporation in this model is determined by

$$
\begin{aligned}
& E=\beta E_{p} \\
& \beta= \begin{cases}\frac{W}{W_{c}}, & W \leq W_{c} \\
1, & W>W_{c}\end{cases} \\
& W_{c}=0.75 W_{f}
\end{aligned}
$$

where $E$ is evaporation, $E_{p}$ is potential evaporation, $W$ is plant-available soil moisture, $W_{c}$ is the critical value of $W$, and $W_{f}$ is the field capacity. This modification will also increase the critical level of $\beta$ in the model, so for dry areas this altered version of the Bucket model evaporates less than in the normal Bucket model.

There were four different versions of $\mathrm{SiB}$ used: SiB, SiB2 (Sellers et al., 1996a,b), and two different versions of SSiB (designated as SSiB-C (COLA) and SSiB-G (Goddard)). SiB2 is an advancement of $\mathrm{SiB}$ because some of the parameters have been improved through use of remotely sensed data, but the hydrology remains unchanged. SSiB, though using half as many parameters as $\mathrm{SiB}$, has been shown to produce output similar to $\mathrm{SiB}$ (Xue et al., 1991). The two groups that used SSiB have made slight alterations to their versions of the models (Mocko, pers. comm., 1998). This project allows comparison of the performance of $\mathrm{SSiB}$ and $\mathrm{SiB}$ on a broader scale than Xue et al. (1991), as well as contrasting $\mathrm{SiB}$ and $\mathrm{SiB} 2$ performance.

BATS is similar to $\mathrm{SiB}$, although it places more emphasis on the transfer of water in the subsurface zone, and less emphasis on the details of the canopy. The largest difference between BATS and the SiB models is in the default parameters for each vegetation type. For example, the version of BATS used in GSWP does not distinguish between C3 and C4 plants.

Mosaic (Koster and Suarez, 1992), which is also based on $\mathrm{SiB}$, brings a different approach to land surface modeling. Mosaic attempts to resolve the subgrid scale heterogeneity of land cover inside a grid cell. Rather than assume that there is only one vegetation type in a grid box (the dominant type), it allows for multiple types and assigns a percentage of land coverage to each vegetation type. It computes a separate energy and water balance for each type, and then combines them (using area averaging) into one balance for the entire grid box. This will make more of a difference in areas where there is a finer network of vegetation, than in areas where one type truly does dominate the grid cell.

The Parameterization for Land-AtmosphereCloud Exchange (Place) model (Wetzel and Boone, 1995) is also slightly different from the other models, in that the Place model is a column model that incorporates the column of air above the land-surface. For this experiment the column aspect of the model was turned off, and it is difficult to determine how this affects the Place model.

The ETA model (Chen et al., 1996) is derived from the Oregon State University LSM (Pan and Mahrt, 1987), and like SSiB, explicitly considers the 
vegetation canopy, soil hydrology, and soil thermodynamics. When used as part of the operational forecast system, it uses Mintz and Serafini (1992) observations for the subsurface and relaxes the values toward those "data," but for GSWP, it was run in stand-alone mode without those restrictions (Chen, pers. comm., 1998).

ISBA (Noilhan and Planton, 1989; Mahfouf et al., 1995) does not differentiate between the root zone and the recharge zone. In the other models, except for the Bucket, there is a root-zone beneath the surface layer, and beneath that is a slower varying recharge zone. Because ISBA combines these two layers into one, the result is a slower varying plant-available soil moisture in the top $1 \mathrm{~m}$ of soil, the main diagnostic unit we use in our comparisons.

\section{Results}

The GSWP experiment was carried out with each model set up to be run on a $1 \times 1^{\circ}$ latitude-longitude grid over the entire land surface of the globe in an off-line mode. Parameters describing the soil type and vegetation were provided on the ISLSCP CD for each model. Each modeler reported three layers of soil moisture: a surface layer; a rooting layer; and, a total soil depth layer. Modelers were allowed to break these layers into sublayers. Soil moisture was reported in wetness percent as well as a volumetric amount for each layer. The modelers also reported a plant-available soil moisture value for the top $1 \mathrm{~m}$, which was the parameter we used for our evaluation. The modelers used the surface and root-zone plantavailable soil moisture to represent the top $1 \mathrm{~m}$ if the root-zone reached a $1 \mathrm{~m}$ depth. If the root-zone was shallower, then the deep layer plant available soil moisture amount was weighted to fill in the additional depth. If the root-zone was deeper than $1 \mathrm{~m}$, then its soil moisture was reduced by the appropriate weight to make it representative of the top $1 \mathrm{~m}$. In addition, the modelers reported many other variables, including surface temperature, canopy water content, latent and sensible heat fluxes, and runoff. The ISLSCP CD also provided the meteorological forcing data, including precipitation, at a 6 -hr resolution.

Modelers were also given spinup instructions. Each model reran 1987 until the root-zone soil moisture values for December 31, 1987, varied by less than $5 \%$ or $5 \mathrm{~mm}$ from the previous year's run, whichever criterion was less stringent. It was suggested that spinup should not be greater than 10 years, but some modelers found it necessary to spin up their models for a greater period. There was no spinup criterion for the deep layer.

Here we evaluate the calculations of plantavailable soil moisture for the top $1 \mathrm{~m}$ for the regions for which we have observations. We have chosen plant-available, as opposed to total soil moisture because it is easier to use when evaluating model performance. It is easy to remember that when the plant available soil moisture reaches zero, it means that the plants are unable to obtain any more water from the soil, and thus transpiration stops.

As the spatial scale of soil moisture variation in all these regions is $300-500 \mathrm{~km}$ (Vinnikov et al., 1996a; Entin, 1998), evaluation on the GSWP grid would incorporate a high level of white noise rather than the climatological signal we would like to examine. Therefore we perform spatial averages over the regions of our observations. In order to avoid signals associated with heterogeneous vegetation cover in the region examined, we average over regions with either natural grassland or agricultural cultivation.

For all but one of the regions, the vegetation at the soil moisture observation locations matches the dominant natural vegetation in the region (Sellers $e t$ al., 1995), and the parameters used by the models will be representative of the observations. For the - Russian Forest region (Fig. 1), the observations were taken at agricultural fields, while the models simulate a forest. Vinnikov et al. (1996a) found that for Valdai, Russia, annual-average soil moisture for the forest just matched grassland soil moisture, but the spring snowmelt peak and subsequent drying was delayed by approximately one month in the forest. Interannual variations were very similar. We cannot be assured that this behavior is universal, but keep it in mind when interpreting results for the Russian Forest box.

There are several different ways to take a spatial average of the soil moisture observations for use in comparison with the gridded model output. One technique is to use a Cressman (1959) scheme to produce a regular grid of data from irregularly spaced stations, and then do an area average just as with the models. Rather, we chose to use the optimal averaging technique developed by Kagan (1979), which has an advantage in that it takes into account the spatial scale of soil moisture and gives less weight to repeated information and more weight to independent information. This is particularly important when there is missing information at particular times, producing a changing distribution of stations. It also produces an estimate of the error of the estimated average. The soil moisture data from Russia had already been averaged from individual stations to a single value given for the district centers, which are fairly evenly distributed. This method also reduces the white noise associated with single measurements. As a result, we decided not to perform further averaging of the data for these regions.

Figure 2 shows the plant-available soil moisture in the top $1 \mathrm{~m}$ produced by the ten different models and the soil moisture observations for each of the regions in Fig. 1. For all the regions, we see a large spread in the soil moisture values of the 
models. The mean of the wetter models is consistently more than $5 \mathrm{~cm}$ wetter than the mean of the drier ones. There are similarly sized discrepancies between model means in the total soil moisture contained in the root-zone (not shown), with an apparent correlation between discrepancy size and rootzone depth. Some of the specific spread in Fig. 2 may be due to the wilting level used by each modeler to compute the plant-available soil moisture for the top $1 \mathrm{~m}$. Although there was information on the ISLSCP CD to compute the wilting level, some modelers used a different value more consistent with their model. It is probably better that modelers used the more consistent wilting level, which ensures that the individual models reduce evaporation, due to lack of water, at the correct level, and that the water holding capacity of the model (defined by the field capacity minus the wilting level) was consistent with that model's original design.

Figure 2 allows for a few interesting observations of overall performance. For all the cases, there is a large spread of soil moisture values of about $15 \mathrm{~cm}$ from the driest to wettest model. If the models had the same relative value with respect to each other and the observations, it would be easy to correct observations by adding or subtracting a constant amount. Unfortunately, this is not the case. This can be more clearly seen by noting the performance of SiB2 in the two different Russia boxes. In the Agricultural box, SiB2 is in the middle group, but is the wettest model in the Forest box. The models do, however, tend to separate into two groups; the wetter group being $\mathrm{SiB} 2, \mathrm{SiB}, \mathrm{SSiB}-\mathrm{C}$, and ETA, and the drier group composed of BATS, Bucket, Place, Mosaic, SSiB-C, and ISBA. SSiB-G actually shows negative values, which was due to inconsistent wilting levels between those used in the model calculations and those used to calculate plant-available soil moisture (Mocko, pers. comm., 1998).

The 1988 drought in Illinois is clear in the observations and in all but two of the models. Three of the models, BATS, SSiB-G, and Mosaic do an excellent job for the period April 1988 to December 1988, including being the only models to properly simulate the large rate of drying in the spring. They are all too dry, however, for the period before that, except for the 1987 summer.

All the models are too dry in Mongolia. As the precipitation forcing appears to be correct (Fig. 3), this points to errors in the forcing or land surface parameters supplied to the models for Mongolia.

For Mongolia and China, there is much less of a seasonal cycle than for the other locations, both in the observations and the models. In the other midlatitude locations, the precipitation is fairly uniformly distributed throughout the year (Fig. 3), while evapotranspiration peaks in the summer. This results in drier soil in the summer, when evapotran- spiration dominates, and wetter soil in winter when precipitation dominates. In Mongolia and China, due to the influence of the summer monsoon, precipitation and evapotranspiration have the same seasonal cycle, both peaking in the summer, thus minimizing the seasonal cycle of soil moisture.

We explore the seasonal cycles in more detail in Fig. 3, where we have created anomalies by removing the 1988 annual mean and also plotted precipitation for each region. This eliminates the biases in mean soil moisture seen in Fig. 2 and makes it easier to compare the seasonal cycles of each model with each other and with observations. We used the 1988 mean to protect against spinup problems that might have given erroneous values in the beginning of 1987. In the design of the GSWP experiment, modelers were asked to repeat the 1987 calculations as many times as necessary until the models reproduced their fields year after year to avoid spinup problems. However, if the end of 1987 was different from the end of the previous year, there still might be residual spinup effects. Therefore we subtracted only the 1988 annual mean to avoid contaminating the calculation of anomalies with spinup effects.

We also plot two precipitation data sets in each panel of Fig. 3, the area-average precipitation from the ISLSCP CD that was used by each model as forcing, and independently observed precipitation from our data bank. There are several reasons for adding a second precipitation data set. The first is that the precipitation data set given on the ISLSCP CD has been derived by using both monthly-observed precipitation and the National Centers for Environmental Prediction reanalysis (Kalnay et al., 1996). We are wary of the reanalysis because it uses a GCM with an LSM, and the resulting calculated land surface climate will be dependent on the particular, unvalidated LSM used. Thus the precipitation patterns it generates are potentially flawed. The second reason for using another precipitation data set is that although the soil moisture is an area average, individual soil moisture observations are heavily influenced by the precipitation that is received at each individual station. The second independent measure of precipitation may possibly explain why the observed soil moisture behaves differently than the models for specific time periods. The average also serves as a check on the ISLSCP precipitation data. For China, the observed precipitation is the average of individual precipitation observations at the soil moisture stations in the area, and for Illinois it is for weather stations in the same region. For Mongolia and Russia, we do not have observed precipitation for the individual stations for the GSWP time period. Instead we have used an independent precipitation data set described by Dai et al. (1997), comprised of monthly averages derived solely from observed precipitation. As all the models were forced 
with the same precipitation, flawed or not, differences between model's performance are due strictly to differences in the models.

\subsection{Russia}

For the different areas of Russia (Figs. 2-3), most of the models assume that when the soil is frozen during the winter the soil moisture remains constant. In fact, this is not the case (Robock et al., 1998) and soil moisture does vary even when the soil is frozen. Explaining how soil moisture is able to change during this period is critical for answering the question of where the water goes when the snow melts, an area of research that has received little attention in the past.

For the agricultural area of Russia, Fig. 3 shows that the models are generally successful in recreating variations in soil moisture during both summers. During June, however, for both types of wheat, the observations show strong drying while the models do not dry nearly as much. The precipitation forcing is close to our observations. Therefore, the model vegetation parameters may not be representative of the actual crop type. Late in the summer, also, observations show that soil moisture begins to increase, and this increase is not simulated by the models. In 1987, the models do not show soil moisture increasing from the summer drought levels until winter. In 1988 , there appears to have been slightly more rain during the summer and fall, so for that year the modeled soil moisture increases in September.

With a few exceptions, the models all behave in a similar fashion. Although the models vary in the total amount of soil moisture, they compute the changes in soil moisture about the same. As noted previously, ISBA is an exception to this. Another exception is BATS which gets wetter than most of the other models during the spring, and then loses more soil moisture than any other model, by the end of summer. SSiB-G seems to have a smaller seasonal cycle and is a bit more sensitive to precipitation events, as the model's soil moisture increases by a larger amount than the other models do, especially around July of both years.

One difference among models is the magnitude of the spring increase. The models seem to fall into two groups. During 1987 one group, comprised of BATS, ISBA, SSiB-C, and SiB2, simulates large increases, in the range of 3-6 cm. The other group, comprised of Place, ETA, and SSiB-G, shows a small increase of approximately $1 \mathrm{~cm}$. During 1988, the grouping is the same, but the size of the increases changes, with the first group showing a smaller increase than in 1987 and the second group showing a larger change. It is difficult to discern what causes this grouping and reversal of fortune. One possible explanation is how each model deals with the spring soil thawing, and resulting placement of liquid from the melting snow.

The second region of study in Russia is in a Forest region (Fig. 3). For a preliminary analysis of changes in soil moisture, it is acceptable to compare the model output, which is based on forest vegetation, against the agricultural soil moisture information from the same area.

As in the cultivation region, the models act quite similarly to each other in the forest region, and during the summer time they are successful in reproducing soil moisture. They all seem to capture the relative change in soil moisture from the beginning of the summer to the end, when soil moisture values are at a minimum. Also, bumps in the seasonal cycle curve - probably caused by precipitation events - seem to be well captured in the models, as depicted by two such events that occurred during the summer of 1988.

As in the cultivation box, one apparent deficiency in the models is that they do not increase in moisture enough during September. However, a longer record period is needed to inspect this problem further. Data from multiple forest regions would be especially helpful in explaining this potential model deficiency.

\subsection{Illinois}

Illinois provides a homogenous region, with grassland or cultivation in most of the area in the box. Figure 3 shows the effects of the two strongest forces on soil moisture, the seasonal cycles of potential evaporation and precipitation. In 1988, the bulk of summer precipitation fell during July and August but it was not enough to significantly wet the soil, and only kept soil moisture steady. During October, a similar, but smaller, amount of precipitation fell. Due to the lower potential evaporation, the soil moisture increased between 4 and $6 \mathrm{~cm}$. The Illinois plot also shows the difference between 1987, a nominal year, and the drought year of 1988, which had less precipitation than during the 1987 spring and a warmer summer. These two deviations from the norm combined to make the 1988 summer drier than the 1987 summer, by about $4-6 \mathrm{~cm}$ in the top $1 \mathrm{~m}$ of soil. Most of the models capture this difference. For some of the drier models the difference between years is less because the soil moisture approached zero in the 1988 summer.

An interesting occurrence is that during the Illinois dry spell in July 1988, there was a precipitation event. The observations show a rise in soil moisture of around $2 \mathrm{~cm}$. Only the bucket model captured the magnitude of the rise. Most of the other models only show a slight rise. One possible explanation is the definition of infiltration rates in the models. As the bucket was not full, all of the precipitation was allowed to enter the bucket, whereas the precipitation was probably too intense for the other models' 
infiltration rates, and thus more of the precipitation was transferred into overland runoff. This is a good example of why further testing of LSMs must be performed using actual observations.

Another interesting occurrence is the re-wetting that occurs in late October. It appears as if some of the drier models lag behind the observations by ten days. Perhaps the infiltration rates of the models are not high enough. A partial explanation is that the models are first wetting the canopy, and thus are losing the first increase in soil moisture, although this should only account for $1 \mathrm{~cm}$ given the vegetation type in Illinois. High frequency soil moisture observations, taken at multiple levels, such as is now being done at the Oklahoma Mesonet (Basara et al., 1998), should give a good contrast between models and observations.

\subsection{China}

For the purpose of this study we use soil moisture data from the central part of eastern China. This gives us the best balance between soil moisture observations that are taken year round and also go down to a depth of $1 \mathrm{~m}$. Figure 3 shows that the models do an adequate job of reproducing the changes in soil moisture. All the models capture the drying that occurs in the summer time, and even catch the brief increase that occurred in May, 1988. The Bucket, ETA and SSiB-C seem to dry out a bit during February 1988, but an intense precipitation event during the middle of March restores them. It is unknown why these particular models dry out before the others. A curious pattern begins in August, 1987. All the models have an increase in soil moisture of around $2 \mathrm{~cm}$ whereas the observations show a drop in soil moisture. The forcing precipitation is rather strong, averaging 4-6 mm/day, explaining the models' behavior. Yet, the observed soil moisture does not see this precipitation, or it is evaporated it back at a higher rate than the models.

The amplitude of the observed month-to-month variations is higher than what all the models simulate. For example, in May, 1988, the observations show a single observation time period above the normally expected summer drying. The models however appear to stay wet for one or two additional periods after the initial peak. For this area of China the models use a deep layer depth of 2 to 3 meters, which is deeper than the other areas examined. This seems to retard the observed rapid change in top $1 \mathrm{~m}$ soil moisture.

\subsection{Mongolia}

The climate of Mongolia seems to be a mix between the climate of the Russian and Chinese regions investigated. The precipitation pattern matches that of China, with a dry winter and wet summer; however, during the winter the soil freezes as it does in Russia. The study area is almost entirely classified as grassland. Figures 2-3 demonstrate that not only do most of the models underestimate soil moisture, but, like China, none of the models appears able to capture the magnitude of soil moisture fluctuations that occur during summertime. The observed soil moisture (Fig. 2) fluctuates during both summers by at least $4 \mathrm{~cm}$ in about a month. No model fluctuates more than $2 \mathrm{~cm}$, with the exception of the Bucket. This model, as discussed above, has no limitations on the amount of precipitation that can enter the soil, assuming nonsaturated conditions. This behavior by the bucket model is evident during 1987, when the model goes from having the largest dry anomaly to the largest wet anomaly after a wet June and July.

Although not able to capture the change magnitude, most models do a good job at simulating the shape of the observed changes, with lows during the early summer followed by highs during late summer. However, none of the models capture the continual drying that occured in the observations during October, 1987. As the solar energy has decreased by that time, it is possible that the models are underestimating the amount of transpiration from vegetation, and thus underestimating the loss of water.

During the summer of $1987, \mathrm{SiB}$ appears to dry out as much as the other models, but does not get wetter when the observation and other models do in August, during high precipitation. Instead, the $\mathrm{SiB}$ model slowly rises in soil moisture, while the observations and other models are coming down from their high anomaly values. It is not until late October that $\mathrm{SiB}$ has recovered. In 1988 a similar pattern begins, although this time $\mathrm{SiB}$ seems to dry out a bit more than the other models and does not recover again during September, when the observations and other models are apparently more able to absorb (and retain) precipitation. However, during 1988 there is less precipitation during October, and potentially there is less moisture in its recharge zone, so $\mathrm{SiB}$ stays with a slightly negative anomaly, while the observations and other models appear to have returned to their mean state.

\subsection{Comparison of spatial fields}

For the following reasons we have opted not to perform any comparisons of the spatial fields of soil moisture. Unfortunately, only two years of data are insufficient to develop a mean seasonal cycle for each grid point. This makes it difficult to compare spatial fields of each model to one another, since ideally it would be best to compare anomaly fields to see how the models are reacting differently spatially. In addition, because each grid point was determined individually without influence from neighboring areas, little information would be gained comparing the model fields to one another. Another problem 


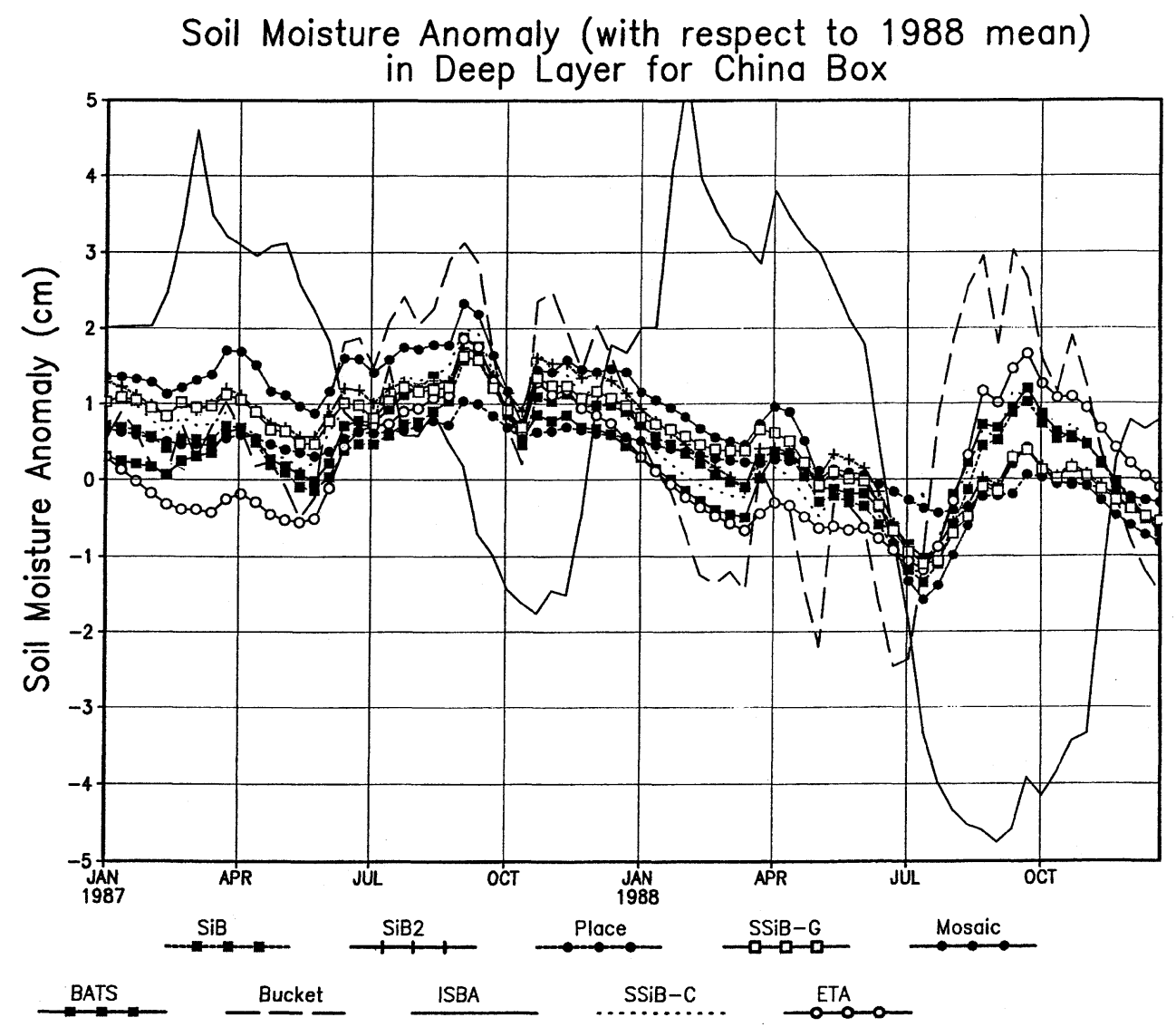

Fig. 4. The same anomaly calculation as in Fig. 3, except for the lowest layer (below the root zone) for each model in the China box. Again, the plant-available soil moisture is given in $\mathrm{cm}$. For both the Bucket and ISBA there is no layer break between the root-zone and the deep layer, causing these models'deep layers to fluctuate more than the other models. There are no soil moisture observations, only model output.

is that a spatial distribution in the models would reflect the differences of mean soil moisture inherent to the different vegetation types of the area covered, whereas the observed soil moisture would only be from a single type of vegetation.

\subsection{Spinup problems}

One of the drawbacks in using only two years of data is the potential for problems due to poor initialization, especially in the lowest layer in each model. Figure 4 shows the lowest layer (the layer beneath the root zone) in each model in the two-year period in the China box (Fig. 1). In most of the boxes, 1987 is wetter than 1988. It is unknown if 1988 was just a drier year than 1987, or if the lowest layer is still adjusting to a drier state than when it was initialized. With only two years it is difficult to even assess if this is a potential problem. If there was a spinup problem, then there is potentially too much or too little water available for the upper layers from the lower layer. As this type of problem would probably take a few years of extreme conditions to affect the rooting layer, the influence for this experiment, on the latent and sensible heat fluxes is probably negligible. However, in the long run it is important to properly initialize the model, especially the lowest layer, because this is the layer that will determine how the soil/vegetation system responds during periods of prolonged drought or water excess.

The other possible ramification of a poorly spun up system, even without a water stress event, is for areas with vegetation with deep root systems. The top meter reaches equilibrium rather quickly in most areas whereas the lower layers take much longer. The time scale for grasslands and cultivation is a couple of months (Vinnikov et al., 1996a; Entin, 1998); it is unknown what the actual time scale is for forest regions. If the root system reaches depths greater than a couple of meters it is possible that those areas were still not in equilibrium when the experiment runs started. Unfortunately, none of the soil moisture data comes from plots with deep root systems. Thus it is difficult to know how well the models functioned in these areas. 


\section{Discussion and conclusions}

The GSWP experiment was able to produce soil moisture fields for the entire globe for 1987 and 1988 . However, there are still many questions about this "data set." No model did a good job at reproducing the amount of plant-available soil moisture in the top soil meter. Although this evaluation is limited to the areas we chose and, more importantly to grassland or agricultural areas, it is appropriate to have a similar concern about other areas. Other areas might have even larger errors, as there have been few validation efforts in the past with areas that are not grassland. In areas where the models use grassland or agriculture vegetation there is the advantage that the root zone is probably not radically different from the one given on the ISLSCP CD. However, for forested areas, the range of root depths is probably much larger, and field capacity for these areas probably has a lot more variance. This means that the mean states of the models could be off by large values. For longer experiments, when such regions experience drought these models could seriously under- or overestimate the amount of moisture the vegetation has available at the inception of the drought.

Therefore, in its goal of producing a global soil wetness data set for use in analyzing climate and initializing GCMs, we consider the GSWP to not have succeeded so far. The main reason is that there is such a wide disparity in the LSM treatments of hydrology that, even with all the models using the same parameters and same forcing, the results are so different that the differences between the models are much larger than the seasonal cycle of soil moisture. While many of the LSMs do a reasonable job of simulating the interannual variation of soil moisture, there is much room for improvement. While improvement of the physical treatment of processes in the models is clearly indicated, the problems may be more in the specification of hydrological and biological parameters for each specific location. Some vegetative parameters can be obtained by remote sensing, but many others require knowledge of subsurface information, which must be in harmony with the specific parameterizations used.

\section{Future recommendations}

Obviously the GSWP experiments have made considerable progress. One of the biggest drawbacks of the experiment is that it ran for only two years. Future ISLSCP experiments should span at least a ten-year period.

A second problem, which is not as easily solved, is the amount of soil moisture data available to verify the models. We anticipate that a few additional data sets of soil moisture (e.g., Iowa and India) will become available in the near future. Unfortunately, there will still be data gaps over large regions of the tropics. One possible solution to this problem is using satellite derived soil moisture to validate the models, with the benefit of the massive increase in land area that would be possible to verify. The same data sets, however, are needed for ground truth for construction of satellite remote sensing algorithms.

Third, catchment scale validation, as done by Schlosser et al. (1997a), is still a quintessential tool used in validating models. Observing the entire water budget is critical in ensuring that a model is working properly and for the correct physical reasons. In addition, projects that involve a smaller area of interest allow for an increase in the temporal resolution of the experiment. As Scott et al. (1995) point out, the complexities of LSMs can cancel each other out when looking at long term results, such as change in soil moisture over a ten day period. To address this, catchment scale experiments can also focus on how models perform time-step to time-step. At this temporal resolution it should be easier to see how the models' performance differs, and possibly determine which is most physically accurate.

Currently, PILPS Phase 2(d) is looking at how well LSMs performed for an 18-year period at Valdai, Russia. This analysis will help answer some questions about how well LSMs perform in regions where the soil freezes during the winter and a snow pack can develop over the winter. This, combined with the expanded data of the future GEWEX CD set, should also help with future GSWP experiments examining how well models perform at multiple locations, and with a variety of vegetation.

The outlook for creating a new soil moisture data set for models to use for initialization is a bit hazy. The results from this project show that there are still problems to be worked out, both with the forcing data as well as the land-surface models used. The dearth of soil moisture data from forest and tropical regions is a significant limitation. We are unable to perform long-term validation of these models for those regions. Hopefully, other approaches using the water balance can improve and validate the land surface models in those regions, and thus lead to accurate soil moisture modeling. One example of this possibility is the data being gathered as part of the Large Scale Biosphere-Atmosphere experiment in Amazonia (LBA), which has a few years of soil moisture data, as well as other observations of the water and energy balance, from both pasture and forest regions in Brazil.

\section{Acknowledgments}

We thank Piers Sellers for leading the initial effort to produce the ISLSCP data sets used as the basis for this experiment, and the leaders of GSWP and all the model participants. We also thank 
Adam Schlosser for lending us his expertise in this area, and Hiroshi Matsuyama for valuable discussions. The Mongolian data were kindly provided by the Ministry of Nature and Environment of Mongolia. This work is supported by NOAA Climate and Global Change Program grant NA56GPO212, and NASA grants NAGW-5227 and NAG55161.

\section{References}

Basara, J.B., K.C. Crawford and R.L. Elliott, 1998: Insitu measurements of soil moisture from the Oklahoma Mesonet: March-June 1997. Preprint Volume of the Tenth Symposium on Observations and Instrumentation, American Meteorological Society, Phoenix, Arizona, January 11-16, 301-306.

Budyko, M.I., 1956: Heat Balance of the Earth's Surface, Gidrometeoizdat, Leningrad, 255pp. (in Russian)

Chen, F., K. Mitchell, J. Schaake, Y. Xue, H.-L. Pan, V. Koren, Q.Y. Duan, M. Ek and A. Betts, 1996: Modeling of land surface evaporation by four schemes and comparison with FIFE observations. J. Geophys. Res., 101, 7251-7268.

Cressman, G.P., 1959: An operational objective analysis system. Mon. Wea. Rev., 87, 367-374.

Dai, A., F.Y. Fung and A.D. Del Genio, 1997: Surface observed global land precipitation variations during 1900-1988. J. Climate, 10, 2943-2962.

Delworth, T. and S. Manabe, 1988: The influence of potential evaporation on the variabilities of simulated soil wetness and climate. J. Climate, 1, 523-547.

Delworth, T. and S. Manabe, 1993: Climate variability and land surface processes. Adv. Water Resour., 16, $3-20$.

Dickinson, R.E., A. Henderson-Sellers, P.J. Kennedy and M.F. Wilson, 1986: Biosphere Atmosphere Transfer Scheme (BATS) for the NCAR Community Climate Model. NCAR Tech. Note NCAR/TN387+STR, 72pp.

Entin, J.K., 1998: Temporal and Spatial Scales of Soil Moisture Variations. Ph.D. dissertation, Department of Meteorology, University of Maryland, College Park, 156pp.

Entin, J.K., A. Robock, S. Liu, K.Y. Vinnikov and G. Peng, 1999: Temporal and spatial variation of soil moisture in China. J. Climate, in preparation.

Gates, W.L., 1992: AMIP: the Atmospheric Model Intercomparison Project. Bull. Amer. Meteor. Soc., 73, 1962-1970.

Giorgi, F., L.O. Mearns, C. Shields and L. Mayer, 1996: A regional model study of the importance of local versus remote controls of the 1988 drought and the 1993 flood over the central United States. J. Climate, 9, 1150-1162.

Henderson-Sellers, A., Z.-L. Yang and R. Dickinson, 1993: The Project for Intercomparison of Landsurface Parameterization Schemes. Bull. Amer. Meteor. Soc., 74, 1335-1349.

Hollinger, S.E. and S.A. Isard, 1994: A soil moisture climatology of Illinois. J. Climate, 7, 822-833.

Houghton, J. T., L.G. Meira Filho, B.A. Callander, N. Harris, A. Kattenberg and K. Maskell, eds., 1996:
Climate Change 1995 - the Science of Climate Change, Cambridge Univ. Press, Cambridge, 584pp.

Kagan, R.L., 1979: Averaging of Meteorological Fields. Gidrometeoizdat, Leningrad. (In Russian). [English translation: 1997. Kluwer, Dordrecht.]

Kalnay, E., M. Kanamitsu, R. Kistler, W. Collins, D. Deaven, L. Gandin, M. Iredell, S. Saha, G. White, J. Woollen, Y. Zhu, A. Leetmaa, R. Reynolds, M. Chelliah, W. Ebisuzaki, W. Higgins, J. Janowiak, K. C. Mo, C. Ropelewski, J. Wang, R. Jenn and D. Joseph, 1996: The NCEP/NCAR 40-year reanalysis project. Bull. Amer. Meteor. Soc., 77, 437-471.

Koster, R.D. and P.C.D. Milly, 1997: The interplay between transpiration and runoff formulations in land surface schemes used with atmospheric models. $J$. Climate, 10, 1578-1591.

Koster, R.D. and M.J. Suarez, 1992: Modelling the land surface boundary in climate models as a composite of independent vegetation stands. J. Geophys. Res., 97, 2697-2715.

Liston, G.E., Y.C. Sud and G.K. Walker, 1993: Design of a Global Soil Moisture Initialization Procedure for the Simple Biosphere Model, NASA Tech. Mem. 104590, National Aeronautics and Space Administration, Greenbelt, Maryland, 138pp.

Mahfouf, J.F., A.O. Manzi, J. Noilhan, H. Giordani and M. Déqué, 1995: The land surface scheme ISBA within the Météo-France climate model ARPEGE. Part I: Implementation and preliminary results. $J$. Climate, 8, 2039-2057.

Manabe, S., 1969: Climate and the ocean circulation, 1. The atmospheric circulation and the hydrology of the earth's surface. Mon. Wea. Rev., 97, 739-774.

Manabe, S., Wetherald, R.T. and R. J. Stouffer, 1981: Summer dryness due to increase of atmospheric $\mathrm{CO}_{2}$ concentration. Clim. Change, 3, 347-384.

Matsuyama, H. and K. Masuda, 1997: Estimates of continental-scale soil wetness and comparison with soil moisture data of Mintz and Serafini. Clim. Dyn., 13, 681-689.

Meeson, B.W., F.E. Corprew, J.M.P. McManus, D.M. Myers, J.W. Closs, K.J. Sun, D.J. Sunday and P.J. Sellers, 1995: ISLSCP Initiative I Global data sets for land-atmosphere models, 19871988. Volumes 1-5, published on CD-ROM by NASA (USA_NASA_GDAAC_ISLSCP_001 USA_NASA_GDAAC_ISLSCP_005).

Mintz, Y. and Y.V. Serafini, 1981: Global Fields of Soil Moisture and Land-surface Evapotranspiration. Research Review - 1980/81, NASA Goddard Space Flight Center Tech. Memo 83907, 178-180.

Mintz, Y. and Y.V. Serafini, 1989: Global Monthly Climatology of Soil Moisture and Water Balance. LMD Internal Report No. 148, Laboratoire de Météorologie Dynamique, Paris France, 102pp.

Mintz, Y. and Y.V. Serafini, 1992: A global monthly climatology of soil moisture and water balance. Clim. Dyn., 8, 13-27.

Namias, J., 1991: Spring and summer 1988 drought over the contiguous United States - causes and prediction. J. Climate, 4, 54-65.

Noilhan, J. and S. Planton, 1989: A simple parameterization of land surface processes for meteorological 
models. Mon. Wea. Rev., 117, 536-549.

Oki, T., T. Nishimura and P. Dirmeyer, 1997: Validating estimates of land surface parameterizations by annual discharge using total runoff integrating pathways. J. Japan Soc. Hydrol. \& Water Resour., 9, 416--425. (in Japanese with English abstract)

Pan, H.-L. and L. Mahrt, 1987: Interaction between soil hydrology and boundary layer development, Boundary Layer Meteor., 38, 185-202.

Robock, A., K.Y. Vinnikov, C.A. Schlosser, N.A. Speranskaya and Y. Xue, 1995a: Use of midlatitude soil moisture and meteorological observations to validate soil moisture simulations with biosphere and bucket models. J. Climate, 8, 15-35.

Robock, A., C.A. Schlosser, K.Y. Vinnikov, S. Liu and N.A. Speranskaya, 1995b: Validation of humidity, moisture fluxes, and soil moisture in GCMs: report of AMIP Diagnostic Subproject 11; Part 1 soil moisture. in W.L. Gates ed. Proceedings of the First International AMIP Scientific Conference, WCRP-92, WMO/TD-No. 732, World Climate Research Programme, Geneva, 85-90.

Robock, A., C.A. Schlosser, N.A. Speranskaya, J.K. Entin and S. Qiu, 1998: Evaluation of AMIP soil moisture simulations. Global Planetary Change, 19, 181-208.

Robock, A., J.K. Entin, K.Y. Vinnikov, A. Namkhai and Ts. Adyasuren, 1999: Mongolian soil moisture variations. J. Climate, in preparation.

Schemm, J., S. Schubert, J. Terry and S. Bloom, 1992: Estimates of Monthly Mean Soil Moisture for 1979 1989. NASA Tech. Mem. 104571, National Aeronautics and Space Administration, Greenbelt, Maryland, $260 \mathrm{pp}$.

Schlosser, C.A., A. Robock, K.Y. Vinnikov, N.A. Speranskaya and Y. Xue, 1997a: 18-Year landsurface hydrology model simulations for a midlatitude grassland catchment in Valdai, Russia. Mon. Wea. Rev., 125, 3279-3296.

Schlosser, C.A., A.J. Pitman, A.G. Slater and A. Henderson-Sellers, 1997b: Experimental design and preliminary results from PILPS Phase 2(d). GEWEX News, 7(4), 9-11.

Scott, R., R.D. Koster, D. Entekhabi and M.J. Suarez, 1995: Effect of a canopy interception reservoir on hydrological persistence in a general circulation model. J. Climate, 8, 1917-1922.

Sellers, P.J., Y. Mintz, Y.C. Sud and A. Dalcher, 1986: A simple biosphere model ( $\mathrm{SiB})$ for use within general circulation models. J. Atmos. Sci., 43, 505-531.

Sellers, P.J., B.W. Meeson, J. Closs, J. Collatz, F. Corprew, D. Dazlich, F.G. Hall, Y. Kerr, R. Koster,
S. Los, K. Mitchell, J. McManus, D. Myers, K.-J. Sun and P. Try, 1995: An overview of the ISLSCP Initiative I Global Data Sets. On: ISLSCP Initiative I-Global Data Sets for Land-Atmosphere Models, 1987-1988. Volumes 1-5. Published on CD by NASA. Volume 1: (USA_NASA_GDAAC_ISLSCP_ 001. OVERVIEW. DOC.)

Sellers, P.J., D.A. Randall, G.J. Collatz, J.A. Berry, C.B. Field, D.A. Dazlich, C. Zhang, G.D. Collelo and L. Bounoua, 1996a: A revised land-surface parameterization (SiB2) for GCMs. Part I: Model formulation, J. Climate, 9, 676-705.

Sellers, P.J., S.O. Los, C.J. Tucker, C.O. Justice, D.A. Dazlich, C.J. Collatz and D.A. Randall, 1996b: A revised land-surface parameterization ( $\mathrm{SiB} 2)$ for GCMs. Part II: The generation of global fields of terrestrial biophysical parameters from satellite data. $J$. Climate, 9, 706-737.

Vinnikov, K.Y. and I.B. Yeserkepova, 1991: Soil moisture: empirical data and model results. J. Climate, 4, 66-79.

Vinnikov, K.Y., A. Robock, N.A. Speranskaya and C.A. Schlosser, 1996a: Scales of temporal and spatial variability of midlatitude soil moisture. J. Geophys. Res., 101, 7163-7174.

Vinnikov, K.Y., A. Robock, J. Entin, V. Zabelin, N.A. Speranskaya and S. Liu, 1996b: Regional scale variations of soil moisture, Preprint Volume, Second International Conference on the Global Energy and Water Cycle (GEWEX, Washington, DC), 176-177.

Vinnikov, K.Y., A. Robock, N.A. Speranskaya and V. Zabelin, 1997: Soil moisture data sets. GEWEX News, 7(2), 8-11.

Watson, R. T., M.C. Zinyowera and R.H. Moss, eds., 1996: Climate Change 1995 - Impacts, Adaptations and Mitigation of Climate Change: Scientific - Technical Analyses, Cambridge Univ. Press, Cambridge, 880pp.

Wetzel, P.J. and A. Boone, 1995: A Parameterization for Land-Atmosphere-Cloud Exchange (Place) documentation and testing of a detailed process model of the partly cloudy boundary-layer over heterogeneous land. J. Climate, 8, 1810-1837.

Xue, Y., P.J. Sellers, J.L. Kinter and J. Shukla, 1991: A simplified biosphere model for global climate studies. J. Climate, 4, 345-364.

Yang, Z.-L., R.E. Dickinson, A. Robock and K.Y. Vinnikov, 1997: On validation of the snow sub-model of the Biosphere-Atmosphere Transfer Scheme with Russian snow cover and meteorological observational data. J. Climate, 10, 353-373. 


\section{全球土壌水分プロジェクトによる土塞水分シミュレーションの評価 \\ Jared K. Entin \\ (メリーランド大学気象学科)}

Alan Robock

(ルッガース大学環境科学科)

Konstantin Y. Vinnikov

(メリーランド大学気象学科)

Vladimir Zabelin

（ロシア水文気象センター）

Suxia Liu

（中国科学院地理研究所）
A. Namkhai

（モンゴル環境調査会社）

Ts. Adyasuren

(モンゴル自然環境省)

全球土壌水分 “データセット”を作成するために、全球土畩水分プロジェクト (GSWP)により、10 個 の異なる陸面モデルが 2 年間 (1987-88) の気象観測値によって駆動された。本研究では、植物が利用可能 な表層 $1 \mathrm{~m}$ の土壤水分量の観測值を、モデルで得られた同じ物理量と比較した。土壤水分量の観測值は口 シア、イリノイ(アメリカ合衆国)、中国、モンゴルの、草地と農業地域から得られた。

どのモデルもどの地域についても実際の土䁃水分量をうまく表現してはいない。従って、GSWPは全 球土壤水分量を産出できることをまだ実証してはいない。しかしながら、ひとたびバイアスさえ取り除い てしまえば、各モデルは様々な地域の土壤水分量の季節変化をよく再現していることが分かった。モデル のバイアスは地域ごとに異なるので、単に平均値を用いて修正するだけでは正しい結果は得られない。パ ラメータをより明確にすること、もしくは物理的・生物的プロセスをもっとよく再現することが、各モデ ルの改良のためにさらに必要である。

将来の GSWP はもっと長い期間のデー夕を用いて行なわれるべきであり、流域スケールの検証や、モ デルの出力の時間分解能をより細かくすることに重点が置かれるべきである。さらに、衛星計測を取り込 むことで増加するであろう土壌水分量の観測值によって、次の研究計画では大いに改善されるであろう。 